\title{
Perilaku Pro Lingkungan Pengurus Organisasi Mahasiswa Pecinta
}

\author{
Alam \\ Randy Pramana Putra ${ }^{1}$ \\ Fakultas Psikologi, Universitas Muhammadiyah Malang \\ e-mail: ${ }^{1}$ randydmp743@gmail.com
}

\begin{abstract}
The current state of the environment is getting worse and therefore required a solution to these problems, environmental problems that occur are a result of human behavior, for the solution also is of human behavior is referred to as proenvironmental behavior. However, members of the student nature lovers college (Mapala) is supposed to be a model for the younger generation to be more concerned about the environment in daily activity still smoke, wear disposable plastic and Mapala work program centered on adventure activities outdoors does not represent the proenvironmental behavior. The purpose of this study was to describe the pro-environmental behavior onboard members Mapala using statistical approach descriptive The study included 77 daily Mapala committee consisting of DIMPA Malang Muhammadiyah University of Malang, IMPALA Brawijaya University, Malang State University Jonggring Salaka, and Tursina State Islamic University of Maulana Malik Ibrahim using total technique sampling. collection data using a scale of General ecological behavior scale (GEBS ). The result showed that Mapala organization committee, who has a high environmental behavior category as many as 41 people (53.2\%) and the lowest is 36 people $(46.8 \%)$.
\end{abstract}

KEYWORDS Pro-Eviromental Behavior, Nature Lover Student College.

CITATION Putra, R. P. (2019). Perilaku pro lingkungan pengurus organsisasi mahasiswa pecinta alam. Cognicia, 7, (3), 378-389.

Lingkungan menjadi sebuah permasalahan yang sedang dibahas terkait banyaknya dampak yang ditimbulkan akibat kerusakan lingkungan. Kekeringan, banjir, tanah longsor, erosi pantai dan sebagainya Aktifitas manusia seperti membuka lahan dengan menebang pohon, berburu hewan-hewan penyeimbang lingkungan dan permasalahan yang pelik dan sering terjadi adalah sampah. Pembukaan lahan dengan penebangan liar hutan-hutan di Indonesia menjadi sebuah faktor kerusakan lingkungan, sampah menjadi factor penyebab pencemaran lingkugan dan semuanya memiliki dampak pemicu bencana di Indonesia. Banyak sungai yang tertutup sampah bisa mengakibatkan banjir, pencemaran air maupun tanah. Penebangan liar pohon di hutan dalam berbagai kepentingan membuat punahnya sebuah ekosistim hewan, tanah longsor maupun perubahan suhu yang ekstrim. Dan hal ini penjadi sebuah perilaku yang disayangkan dari adanya aktifitas manusia.

Ada banyak analisis atau penelitian yang dilakukan di Indonesia ataupun penelitian luar negeri yang berkaitan dengan lingkungan dan perilaku manusianya. Permasalahan lingkungan yang banyak terjadi disebabkan oleh kurangnya kesadaran 
masyarakat dalam memahami alam. Masyarakat memandang bahwa manusia sebagai pusat dari alam semesta yang mempunyai nilai dan berharga pada dirinya sendiri, sementara alam dan isinya hanya sebagai sarana untuk memenuhi kepentingan manusia. Kesalahan cara pandang ini melahirkan perilaku yang salah terhadap lingkungan. Paradigma yang membawa masyarakat untuk mengeksploitasi sumber daya alam secara berlebihan tanpa memperhatikan kelestarian lingkungan hidup (Irfianti, Khanafiyah dan Astuti, 2016).

Banyak contoh kerusakan lingkungan yang disebabkan oleh perilaku manusia, seperti banjir, kebakaran hutan, pencemaran tanah maupun udara, dan lainnya. Banjir sudah menjadi bencana rutin pada musim penghujan di beberapa kota besar di Indonesia, kebakaran hutan juga hampir terjadi setiap tahunnya di wilayah hutan yang ada di Indonesia. Beberapa alasan terjadinya banjir disebabkan oleh perilaku masyarakat yang membuang sampah sembarangan, mengganti lahan resapan air seperti hutan kota menjadi pemukiman, dan lain sebagainya. Begitu juga dengan kebakaran hutan, baik yang disengaja ataupun tidak. Seperti beberapa kasus yang disimpulkan juga terjadi akibat perilaku manusia itu sendiri. Merokok dan membuang putung rokok sembarangan di hutan, membuka lahan dengan cara membakar hutan akhirnya meluas dari sasaran, dan juga memang sengaja untuk membakar lahan hutan itu sendiri.

Menurut Betley (2004) rendahnya kepedulian masyarakat dalam menjaga dan merawat lingkungan merupakan faktor utama yang mempengaruhi kelestarian lingkungan. Kerusakan lingkungan yang terjadi tentunya berdampak terhadap masalah psikologis individu, seperti rendahnya tingkat kepuasan individu terhadap kondisi lingkungan hidupnya dapat diminimalkan jika individu mampu menampilkan perilaku yang lebih positif, seperti tidak membuang sampah sembarangan, menjadi relawan penyelamatan serta meningkatkan kepedulian terhadap lingkungan. Salah satu tujuan utama pengelolaan lingkungan hidup adalah terselenggaranya pembangunan berwawasan lingkungan dan pemanfaatan sumber daya alam secara bijaksana.

Aktifitas manusia sehari-hari terkait dengan sikap dan perilaku manusia itu sendiri. Perilaku itu sendiri merupakan respon atau reaksi seseorang terhadap stimulus atau rangsangan dari luar. Perilaku ini terjadi melalui proses adanya stimulus terhadap orang lain dan kemudian seseorang tersebut merespon stimulus tersebut (Azwar, 2009). (Notoatmodjo, 2011) merumuskan bahwa perilaku merupakan respon atau reaksi seseorang terhadap stimulus (rangsangan dari luar). Dari sini dapat disimpulkan bahwa perilaku merupakan sebuah respon berupa tindakan hasil dari penerimaan stimulus.

Perilaku manusia dipengaruhi oleh begitu banyak faktor-faktor internal dan eksternal dari dimensi masa lalu, saat ini dan masa datang. Meski demikian, seperti yang telah dipaparkan di awal bahwa faktor-faktor tersebut terlibat secara kompleks dalam mempengaruhi perilaku pro-lingkungan, sebab pada dasarnya perilaku manusia tidaklah sederhana untuk dipahami dan diprediksi (Azwar, 2015).

Perilaku pro-lingkungan adalah tindakan yang bertujuan untuk menimimalisir kerusakan lingkungan atau memperbaiki kondisi lingkungan (Saputra, Febriana, \& Akbar, 2018). Perilaku pro lingkungan didefinisikan sebagai tindakan yang disengaja 
untuk memberi manfaat kepada orang lain, keinginan mengorbankan diri demi lingkungan (Valentine, 2010). Perilaku pro lingkungan akan kuat ketika individu memiliki pengetahuan di bidang lingkungan dan menunjukannya kepada orang lain, sehingga memudahkan orang untuk bertindak sejalan dengan tujuan yang ingin ditetapkan (Robertson, 2016).

Perilaku Pro Lingkungan merupakan tindakan yang berguna untuk meminimalisir kerusakan lingkungan atau memperbaiki kondisi lingkungan, perilaku ini seperti melakukan recycling merupakan tindakan mengolah atau menggunakan kembali sampah, environmentally responsible consumption merupakan keinginan untuk membeli produk yang ramah lingkungan, energy conservation merupakan keinginan untuk melakukan penghematan listrik di rumah tangga, dan transportation behaviour merupakan keinginan menggunakan transportasi umum daripada mobil pribadi (Scannel dalam Elisa: 2014). Menurut Gifford (2014) faktor yang mempengaruhi pro lingkungan adalah pengalaman masa kecil, pengetahuan dan pendidikan, kepribadian, locus of control, nilai, pandangan politik dan pandangan dunia, tujuan, rasa tanggung jawab, place attachment, usia, gender. Dari faktor-faktor yang mempengaruhi pro lingkungan tersebut, dapat diketahui cara untuk meningkatkan perilaku pro lingkungan.

Pentingnya perilaku pro lingkungan untuk merevitalisasi lingkungan sangat diperlukan. Beberapa program juga sudah dicanangkan oleh pemerintah maupun swasta terkait dengan perilaku pro lingkungan, seperti adanya pencanangan 1000 pohon, bank sampah, bersih sungai Brantas (Arifina, 2019), dan masih banyak lagi program lain yang dilakukan sebagai wujud perilaku pro lingkungan. Hal ini sangat membutuhkan kesadaran tinggi dari masyarakat untuk peduli lingkungan. Mahasiswa menjadi salah satu bagian dari masyarakat yang dinilai memiliki nilai intelktual tinggi dengan mengenyam pendidikan tinggi diharapkan bisa menjadi subjek representatif yang memiliki perilaku pro lingkungan yang baik.

Selain itu, pendidikan merupakan salah satu variabel yang penting dalam menjelaskan tingkat perhatian dan perilaku lingkungan (Zilahy dan Huisingh, 2009; Zsóka, Szerenyi, Scechy, Kocsis, 2012). Penelitian terdahulu menyatakan bahwa orang yang tingkat Pendidikanya lebih tinggi kecenderungan lebih peduli tentang kualitas lingkungan serta termotivasi untuk terlibat dalam kelestarian lingkungan. Hal ini dikarenakan terdapat kesadaran akan potensi kerusakan (Lozano, 2006). Universitas adalah sarana pendidikan yang berperan aktif dalam mengarahkan mahasiswanya untuk memiliki nilai-nilai kepedulian sosial secara efektif. Kampus yang berwawasan lingkungan menjadi wacana penting di berbagai perguruan tinggi dalam memberikan sumbangsih untuk mengatasi permasalahan lingkungan secara global. Sistem Manajemen Lingkungan (Enviromental Management System) telah diterapkan di beberapa universitas Eropa sebagai cara mendukung program kampus yang berkelanjutan (Frank dan Meyer, 2007).

Unit Kegiatan Mahasiswa (UKM) Pecinta Alam yang ada di setiap perguruan tinggi merupakan wadah bagi para mahasiswa pecinta alam. UKM ini juga memiliki banyak program dan kegiatan yang berkaitan dengan alam. Secara tidak langsung, anggota dan pengurus dari UKM MAPALA ini merupakan mahasiswa yang peduli dengan alam. Namun sejauh ini, dari hasil pengamatan peneliti, peneliti hanya melihat 
banyaknya program kerja serta Pendidikan pelatihan dasar ataupun lanjutan UKM mahasiswa pencinta alam lebih fokus di kegiatan olahraga alam bebas dan tidak selaras dengan kodek etik pecinta alam yang menyatakan Memilahara alam beserta isinya serta menggunakan sumber alam sesuai dengan kebutuhanya.

Adapun aktifitas Mapala sendiri kurang bisa mencerminkan sebagai representasi pecinta alam dan lingkungan. Banyak pengurus mapala baik itu pengurus harian maupun anggota yang juga masih merokok, dimana asap rokok dapat mengganggu pernafasan bagi perokok ataupun lingkunganya. Membuang sampah masih sembarangan, masih sering menggunakan bahan plastik dalam kehidupan sehariharinya maupun penggunaan alat transportasi yang menyebabkan polusi. Tanpa disadari, aktifitas mereka juga memberikan kontribusi dalam mengganggu kelestarian lingkungan.

Dari uraian permasalahan yang menyebutkan keterkaitan antara perilaku manusia dengan alam dimana manusia memiliki kontribusi besar terhadap kerusakan alam, menarik peneliti untuk melakukan penelitian tentang perilaku pro lingkungan. Hal ini yang kemudian menjadi acuan peneliti untuk melakukan penelitian tentang bagaimana perilaku pro lingkungan pengurus organisasi Mapala di Malang, dimana peneliti mengambil objek penelitian di Mapala Universitas Muhammadiyah Malang, Universitas Brawijaya, Universitas Negeri Malang dan UIN Maulana Malik Ibrahim Malang. Adapun yang menjadi alasan adalah dikarenakan sejauh ini berdasarkan informasi dan pengamatan peneliti, pengurus Mapala merupakan pengurus aktif di UKM Mapala masing-masing, kemudian pengurus Mapala yang tahu tentang-tentang program yang dimiliki UKM masing-masing dan juga lebih terstruktur.

Penelitian ini bertujuan untuk mengetahui dan mendeskripsikan tentang perilaku pro lingkungan organisasi Mapala di Malang. Adapun manfaat secara teoritis dari penelitian ini diharapkan bisa menjadi tambahan referensi tentang perilaku pro lingkungan kepada peneliti sejenis selanjutnya dan juga bisa menambah kajian ilmu tentang pro lingkungan. Manfaat secara praktis, hasil penelitian ini nantinya diharapkan bisa menjadi wacana atau refleksi kepada organisasi Mapala yang ada di Malang khususnya yang menjadi subjek penelitian.

\section{METODE}

Tipe penelitian yang digunakan adalah statistik deskriptif dan sifat penelitian ini adalah kuantitatif non eksperimen. Penelitian ini mendeskripsikan keadaan objek atau permasalahaan tanpa ada maksud untuk membuat kesimpulan dan generalisasi. Analisis statistik yang digunakan dalam penelitian jenis ini adalah statistik deskripsif yang bisa berupa tabulasi persentase, tabulasi silang, ataupun bentuk-bentuk grafik dan sebagainya.

Subjek penelitian dalam penelitian ini adalah pengurus UKM Mapala di Malang sebanyak 77 pengurus, yang terdiri dari 24 pengurus di DIMPA UMM, 23 pengurus di IMPALA Universitas Brawijaya, 21 pengurus di UKM Jonggring Salaka Universitas Negeri Malang, dan 9 pengurus UKM Tursina UIN Maulana Malik Ibrahim Malang. Dari jumlah keseluruhan subjek penelitian, teknik penentuan subjek ini menggunakan teknik total sampling. Total sampling merupakan teknik pengambilan sampel dimana jumlah sampel sama dengan populasi dan jumlah populasi kurang dari 100 (Sugiyono, 
2007). Adapun karakteristik subjek dalam penelitian ini adalah pengurus Mapala yang mengetahui tentang program kegiatan di Mapala dan pengurus yang pernah mengikuti kegiatan pro lingkungan.

Variabel penelitian yang digunakan dalam penelitian ini adalah variabel perilaku pro lingkungan. Dimana perilaku pro lingkungan merupakan tindakan dari individu untuk meminimalisir kerusakan lingkungan dengan menggunakan berbagai cara berdasarkan pengalamannya. Instrument penelitian dalam penelitian ini adalah berupa kuesioner General Ecological Behavior Scale (GEBS) yang di adaptasi dari 6 aspekaspek pro lingkungan menurut (Kaiser, 2004) yaitu; konservasi energy, mobilitas dan transportasi, menghindari limbah, daur ulang, konsumerisme dan kontservasi. Adapun dalam kuesioner tersebut nantinya berupa pernyataan yang didalamnya juga terdapat opsi pilihan jawaban sangat setuju (SS) dengan skor 5, setuju (S) dengan skor 4, Netral (N) dengan skor 3, tidak setuju (TS) dengan skor 2, dan sangat tidak setuju (STS) dengan skor 1.

Tabel 1. Indeks Validitas dan Reliabilitas Instrumen Penelitian

\begin{tabular}{lcccc}
\hline \multicolumn{1}{c}{$\begin{array}{c}\text { Instrumen } \\
\text { Penelitian }\end{array}$} & $\begin{array}{c}\text { Jumlah Item } \\
\text { diujikan }\end{array}$ & $\begin{array}{c}\text { Jumlah } \\
\text { Item Valid }\end{array}$ & $\begin{array}{c}\text { Indeks } \\
\text { Validitas }\end{array}$ & $\begin{array}{c}\text { Nilai Reliabilitas } \\
\text { (Cronbach's Alpha) }\end{array}$ \\
\hline $\begin{array}{l}\text { General } \\
\begin{array}{l}\text { Ecological } \\
\text { Behavior (GEBS) }\end{array}\end{array}$ & 40 & 24 & $0.301-0.649$ & 0.864 \\
\hline
\end{tabular}

Peneliti melakaukan Try Out terpakai, berdasarkan uji validitas yang telah dilakukan, terdapat 6 item yang gugur dari 40 jumlah item skala, yaitu pada item nomor 11, 15, 31, 36, 37 dan 39. Kemudian di uji coba kembali menggunakan item-item yang sudah gugur ditemukan beberapa item yang tidak valid, yaitu pada nomor 8, 9, $10,14,16,17,26,30,32$, dan 38. Jadi item yang dikatakan valid dan dapat dilanjutkan untuk penganalisaan data sebanyak 24 item dari 40 item yang sudah dibuat sebelumnya.

Pada awal penelitian ini, peneliti merumuskan skala pada kuesioner berupa pernyataan tentang perilaku pro lingkungan. Sebelum dilaksanakan penelitian secara langsung dengan menggunakan kuesioner tersebut, tahap selanjutnya peneliti melakukan try out atau uji coba atas validitas dan reliabilitas instrument penelitian berupa kuesioner. Item kuesioner yang valid kemudian digunakan sebagai kuesioner pada penelitian sebenarnya. Setelah data terkumpul melalui hasil jawaban atas kuesioner, peneliti menabulasikan skor untuk mengklasifikasikan data sesuai dengan organisasi MAPALA subjek dan untuk memudahkan peneliti dalam penganalisaan data.

Data yang sudah ditabulasikan dianalisa dengan menggunakan analisis rata-rata (mean). Dari hasil rata-rata tersebut, peneliti mengetahui mayoritas jawaban subjek penelitian pada masing-masing aspek penelitian, yang kemudian dibahas dan di diskusikan dengan teori yang terkait dengan pro lingkungan. 
HASIL

Tabel 2. Deskripsi Subjek

\begin{tabular}{lcc}
\hline Deskripsi & Frekuensi & Persentase (\%) \\
\hline Jenis Kelamin & 62 & \\
$\quad$ Laki-laki & 15 & $80.5 \%$ \\
$\quad$ Perempuan & & $19.5 \%$ \\
\hline Usia & 19 & $24.7 \%$ \\
18 & 32 & $41.6 \%$ \\
19 & 13 & $16.9 \%$ \\
20 & 13 & $16.9 \%$ \\
21 & & \\
Semester & 31 & $40.3 \%$ \\
3 & 16 & $20.8 \%$ \\
5 & 11 & $14.3 \%$ \\
7 & 19 & $24.7 \%$ \\
9 & & \\
\hline MAPALA & 24 & $31.2 \%$ \\
DIMPA & 23 & $29.9 \%$ \\
IMPALA & 21 & $27.3 \%$ \\
Jonggring Salaka & 9 & $11.7 \%$ \\
Tursina & 77 & $\mathbf{1 0 0} \%$ \\
\hline
\end{tabular}

Dari total 77 subjek penelitian ini, jumlah responden didominasi oleh subjek yang berjenis kelamin laki-laki sebanyak 62 orang (80.5\%) dan 15 orang sisanya adalah perempuan (19.5\%). Rentang usia subjek berkisar antara 18 hingga 21 tahun ke atas dan subjek yang berusia 18 tahun berjumlah 19 orang (24.7\%), disusul subjek yang berusia 19 tahun berjumlah 32 orang (41.6\%) kemudian subjek yang berusia 20 dan 21 tahun dengan jumlah yang sama 13 orang (16.9\%), dan subjek berusia 18 tahun memiliki jumlah subjek 19 orang $(24.7 \%$.). Di lihat dari semester pendidikan, jumlah yang mendominasi adalah subjek pada semester 3 sebanyak 31 orang (40.3\%), subjek pada semester 5 sebanyak 16 orang (20.8\%), subjek pada semester 7 sebanyak 11 orang $(14.3 \%)$ dan semester 9 sebanyak 19 orang $(24.7 \%)$. Adapun dari responden organisasi mahasiswa pecinta alam, jumlah yang mendominasi adalah DIMPA sebanyak 24 orang $(31.2 \%)$, IMPALA sebanyak $23(29.9 \%)$, Jonggring Salaka sebanyaka 21 orang $(27.3 \%)$ dan Tursina sebanyak 9 orang $(11.7 \%)$.

Tabel 3. Kategori Perilaku Pro Lingkungan

\begin{tabular}{cccc}
\hline Kategori & Interval & Frekuensi & Persentase \\
\hline Tinggi & $T$-Score $>50$ & 41 & $53.2 \%$ \\
Rendah & $T$-Score $\leq 50$ & 36 & $46.8 \%$ \\
\hline Total & & 77 & $\mathbf{1 0 0 \%}$ \\
\hline
\end{tabular}


Dari Tabel 3, diperoleh bahwa data penelitian menunjukkan dari total 77 orang subjek, sebanyak 41 orang dikategorikan memiliki perilaku pro lingkungan yang tinggi dengan persentase sebesar $53.2 \%$ dan yang dikategorikan memiliki perilaku pro lingkungan yang rendah sebanyak 36 orang dengan persentase sebesar $46.8 \%$

Tabel 4. Aspek-aspek Perilaku Pro Lingkungan

\begin{tabular}{lcccc}
\hline \multirow{2}{*}{\multicolumn{1}{c}{ Aspek }} & \multicolumn{2}{c}{ Rendah } & \multicolumn{2}{c}{ Tinggi } \\
\cline { 2 - 5 } & F & $\mathbf{\%}$ & F & $\mathbf{\%}$ \\
\hline Konservasi Energi & 35 & 45.5 & 42 & 54.5 \\
\hline Mobilitas dan Transportasi & 34 & 44.2 & 43 & 55.8 \\
\hline Menghindari Limbah & 25 & 32.5 & 52 & 67.5 \\
\hline Daur Ulang & 40 & 51.9 & 37 & 48.1 \\
\hline Konsumerise & 34 & 44.2 & 43 & 55.8 \\
\hline Konservasi & 35 & 45.5 & 42 & 54.5 \\
\hline
\end{tabular}

Berdasarkan tabel 4 di atas dapat diketahui dalam aspek konservasi energi, sebanyak 42 orang (54.5\%) masuk dalam kategori yang tinggi sedangkan 35 (45.5\%) orang responden lain masuk dalam kategori rendah. Pada aspek mobilitas dan transportasi, 43 (55.8) orang masuk dalam kategori tinggi (55.8\%) dan 34 (44.2\%) orang responden masuk dalam kategori rendah. Pada aspek menghindari limbah sebanyak 52 orang $(67.5 \%)$ masuk dalam kategori tinggi dan 25 orang $(32.5 \%)$ masuk dalam kategori rendah. Pada aspek daur ulang sebanyak 37 orang $(48.1 \%)$ masuk dalam kategori tinggi dan 40 (51.9\%) masuk dalam kategori rendah. Pada aspek konsumerisme sebanyak 38 orang (49.4\%) masuk dalam kategori tinggi dan 39 orang (50.6\%) masuk dalam kategori rendah. Pada aspek Konservasi sebanyak 42 orang $(54.5 \%)$ masuk dalam kategori tinggi dan 35 orang (45.5\%) masuk dalam kategori rendah.

Tabel 5. Perilaku Pro Lingkungan Berdasarkan Demografis Responden

\begin{tabular}{lcccc}
\hline \multirow{2}{*}{ Klasifikasi } & \multicolumn{4}{c}{ Perilaku Pro Lingkungan } \\
\cline { 2 - 5 } & \multicolumn{2}{c}{ Rendah } & \multicolumn{3}{c}{ Tinggi } \\
\cline { 2 - 5 } & F & \% & F & $\%$ \\
\hline Jenis Kelamin & & & & \\
Laki-laki & 29 & 46.8 & 33 & 53.2 \\
$\quad$ Perempuan & 7 & 46.7 & 8 & 53.3 \\
\hline Usia & & & & \\
18 Tahun & 9 & 47.4 & 10 & 52.6 \\
19 Tahun & 15 & 53.1 & 17 & 53.1 \\
20 Tahun & 5 & 61.5 & 8 & 61.5 \\
21 Tahun & 7 & 46.2 & 6 & 46.2 \\
\hline Semester & & & & \\
Semester 3 & 17 & 54.8 & 14 & 45.2 \\
Semester 5 & 7 & 43.8 & 9 & 56.3 \\
Semester 7 & 4 & 36.4 & 7 & 63.6 \\
Semester 9 & 8 & 42.1 & 11 & 57.9 \\
\hline
\end{tabular}




\begin{tabular}{lcccc}
\hline Mapala & & & & \\
DIMPA & 11 & 45.8 & 13 & 54.2 \\
IMPALA & 9 & 39.1 & 14 & 60.9 \\
Jongring Salaka & 11 & 52.4 & 10 & 47.6 \\
Tursina & 5 & 55.6 & 4 & 44.4 \\
\hline
\end{tabular}

Berdasarkan Tabel 5 diketahui dari 35 Pengurus UKM Mapala Laki-laki memiliki Kategori Perilaku Pro Lingkungan yang tinggi terdiri dari 33 orang (53.2\%) dan yang rendah sebanyak 29 orang (46.8\%). Pada Anggota pengurus perempuan yang memeliki Kategori Perilaku Pro Lingkungan yang tinggi terdiri dari 8 orang (53.3\%) dan 7 orang yang rendah (46.7\%). Sedangkan pada pengurus organisasi yang berusia 18 tahun memiliki kategori perilaku pro lingkungan yang tinggi sebanyak 10 orang (52.6\%) dan yang rendah sebanyak 9 orang (47.4\%). Pada pengurus organisasi berusia 19 tahun sebanyak 17 orang (53.1\%) memiliki kategori perilaku pro lingkungan yang tinggi dan 15 orang (46.9\%) rendah. Pada pengurus organisasi umur 20 memiliki kategori perilaku pro lingkungan yang tinggi sebanyak 8 orang $(61.5 \%)$ dan yang rendah 5 orang (38.5\%). Pada pengurus organisasi umur 21 memiliki kategori perilaku pro lingkungan yang tinggi berjumlah 6 orang (46.2\%) dan yang rendah 7 orang (53.8\%). Diperoleh pula data berdasakaran semester bahwa jenjang Pendidikan pengurus organisasi yang semester 4 memiliki perilaku pro lingkungan yang tinggi sejumlah 14 orang responden $(45.2 \%)$ dan rendah 17 orang (54.8\%). Pada pengurus organisasi semester 5 memiliki perilaku pro lingkungan yang tinggi sejumlah 9 orang (56.3\%) dan terendah 7 orang (43.8\%). Pada pengurus organisasi semester 7 yang memiliki perilaku pro lingkungan yang tinggi sejumlah 7 orang $(63.6 \%)$ dan terendah 4 orang (36.4\%). Sementara pada Pengurus organisasi semester 9 yang memiliki Perilaku Pro Lingkungan yang tinggi terdapat 11 orang (57.9\%) dan terendah 8 orang (42.1\%). Kemudian berdasarkan UKM Mapala dapat diketahui bahwa pengurus orangasisasi DIMPA memiliki perilaku pro lingkungan tinggi sejumlah 13 orang (54.2\%) dan yang rendah 11 (45.8\%), Sementara Pengurus Organisasi IMPALA yang memiliki perilaku pro lingkungan tinggi sejumlah 14 orang (60.9\%) dan terendah 9 orang (39.1\%). Pada Penguru Organisasi Jonggring Salaka yang memiliki perilaku pro lingkungan yang tinggi sejumlah 10 orang (47.6\%) dan terendah 11 orang (52.4\%). Pada Pengurus organisasi Tursina yang memiliki perilaku pro lingkungan yang tinggi sejumlah 4 orang $(44.4 \%)$ dan terendah 5 orang $(55.6 \%)$.

\section{DISKUSI}

Berdasarkan dari hasil penelitian diketahui perilaku pro lingkungan dari responden mendapatkan hasil 41 orang responden $(53,2 \%)$ memiliki kategori pro lingkungan yang tinggi dan $36(46,8 \%)$ orang responden memiliki kategori pro lingkungan yang rendah. Hal ini dapat diartikan bahwa pengurus UKM Mapala yang terdiri dari Dimpa dari Universitas Muhammadiyah Malang, Impala dari Universitas Brawijaya, Jonggring Salaka dari Universitas Negeri Malang, Tursina dari Universitas Negeri Islam Maulana Malik Ibrahim memiliki perilaku pro lingkungan yang Tinggi, dimana hal ini ditunjukkan dari hasil analisis data yang menunjukkan kategori 
perilaku pro lingkungan yang tinggi lebih tinggi nilainya dari perilaku pro lingkungan yang rendah. Hal ini juga berlaku pada masing-masing aspek perilaku pro lingkungan.

Pada Konsumerisme, sebanyak 43 (55.8\%) orang masuk dalam kategori yang tinggi sedangkan 34 (44.2\%) orang masuk dalam kategori rendah. Dalam penelitian (Dewi, Rusdarti, \& Sunarto, 2017) menyatakan bahwa Media Sosial berpengaruh signifikan secara positif terhadap perilaku konsumtif pada mahasiswa. Media sosial memberikan porsi bersar mendorong timbulnya perilaku konsumtif pada mahasiswa karena media sosial menjadi tempat berkumpulnya informasi yang dengan cepat dapat mempengaruhi gaya hidup seseorang untuk berperilaku konsumsitf karena dianggap penting untuk mengikuti tren saat ini. Kesimpulan yang dapat diambil dari penelitian ini adalah bahwa perilaku konsumtif di kalangan mapala mengalami perubahan dalam waktu yang relatif singkat dan cenderung berlebihan (mewah) seiring berkembangnya teknologi informasi seperti layanan pesan antar makanan online, penjualan berbagai segala macam kebutuhan di internet lalu kemunculan pusat perbelanjaan dan hiburan secara masif (Mall dan Café).

Pada aspek Konservasi energi dan Konsevarsi sama-sama memiliki kategori perilaku pro lingkungan yang tinggi sebanyak 42 responden (54.5\%) dan sebanyak 35 $(45.5 \%)$ responden masuk dalam kategori rendah. Dalam hal ini terdapat pertentangan antara konservasi dan pemanfatan sumber daya alam untuk kebutuhan manusia, sebagaimana Orientasi nilai individu menentukan tindakannya. Pilihan individu untuk pro atau kontra konservasi dipengaruhi oleh orientasi nilainya. Individu yang berorientasi pada ekonomi lebih mendukung praktek pengelolaan hutan tebang habis dari pada individu yang berorientasi ekologis (Abrams, Kelly, Shindler, \& Wilton, 2005). Individu yang berspektif ekonomi cenderung lebih mendukung penggunaan hutan untuk manusia seperti halnya pembalakan hutan untuk kepentingan manusia, pertambangan, dan rekreasi, sementara dalam penelitian (Brown \& Reed, 2000) individu yang bersifat biosentrik lebih mendukung kebijakan yang meminimalisir invervensi manusia atas sumber daya hutan, misalnya membatasi tebang habis, membuat rimba belantara dan melindungi hutan-hutan tua, sedangkan dalam hasil wawancara dan pengamatan peneliti terhadap responden melihat beberapa mapala saat ini hanya memfokuskan kegiatan di bidang olahraga alam bebas dan mengabaikan kode etik pecinta alam yang disusun dan disahkan bersama dalam acara gladian ke- IV di Ujung Pandang, tahun 1974 pada poin ke dua memelihara alam beserta isinya serta menggunakan sumber daya alam sesuai dengan kebutuhan.

Pada aspek Menghindari limbah 52 (67.5\%) responden masuk dalam kategori perilaku pro lingkungan yang tinggi dan aspek daur ulang $37(48,1 \%)$ responden masuk dalam kategori tinggi. Dalam hasil wawancara dengan responden mengatakan bahwa mereka tidak mau ribet dan menunda waktu. Sama halnya ketika ditawari kantong plastik saat belanja di mini market kebanyakan responden menerimanya tanpa memikirkan jangka panjang penumpukan plastik sekali pakai yang mereka dapatkan, merujuk pada hasil penelitian (Jambeck, 2015) Indonesia menyumbang sampah plastik sebanyak 3,32 juta ton atau berada di posisi kedua setelah China. Masifnya tingkat konsumsi sampah plastik saat ini tidak berimbang dengan tata kelola sampah atau daur ulang limbah yang memadai. Dari hasil penelitian (Putra, Adyatma, \& Normelani, 2016) bahwa terjadi penurunan kualitas air sungai akibat perilaku 
membuang sampah dan aktivitas MCK (membuang, cuci, kakus) masyarakat di bantaran sungai martapura serta Sungai Martapura dinyatakan tercemar ringan setelah dilakukan pengukuran kualitas air sungai menggunakan parameter warna air, bau air, rasa air, TSS, $\mathrm{pH}, \mathrm{DO}$ dan plankton. Disinilah seharusnya peran instansi ataupun organisasi untuk mengkritisi dan menyepakati aturan untuk mengatasi pencemaran agar tidak terus berlangsung, seperti halnya organisasi mapala kampus yang dapat menjadi menjadi koordinator pengelolahan limbah sampah plastik menjadi biji plastik dalam skala universitasnya masing-masing.

Kemudian pada aspek Mobilitas dan Transportasi sebanyak 43 responden $(55,8 \%)$ masuk dalam kategori perilaku pro lingkungan yang tinggi dan $34(44.2 \%)$ masuk dalam kategori rendah. Pada hal ini sangat penting untuk memahami besarnya pengaruh penggunaan alat transportasi yang digunakan dalam aktivitas sehari-hari memberi dampak sangat besar bagi kualitas udara melalui gas buang dari kendaraan bermotor. Meninjau pada peneltian (Yusrianti, 2015), aktivitas transportasi khususnya kendaraan bermotor merupakan sumber utama pencemaran udara di daerah perkotaan, pencamaran udara dapat di definisikan sebagai atmosfer yang terdiri dari senyawa-senyawa engan konsentrasi tinggi diatas kondisi udara ambien normal, sehingga menimbulkan dampak negatif bagi manusia, hewan vegetasi, maupun benda lainnya. Masalah lingkungan adalah tanggung jawab masyarakat dan pemerintah untuk menangani sekaligus mengantasipasi pencemaran dan kerusakan lingkungan yang terus menerus terjadi.

Adapun keterbatasan dalam penelitian ini adalah item-item yang digunakan dalam aspek perilaku pro lingkungan yang dirasa kurang sesuai dengan lingkungan dan alam di Indonesia karena merupakan item yang di adopsi dari penelitian internasional. Oleh sebab itu untuk penelitian selanjutnya dapat menggunakan atau membuat item lain dalam pembuatan sekala meskipun menggunakan rujukan dari aspek perilaku pro lingkungan dalam penelitian ini. Sehingga item pernyataan maupun pertanyaan bisa disesuaikan dengan situasi dan kondisi lingkungan yang ada di Indonesia. Kemudian penelitian lain yang sejenis selanjutnya bisa menggunakan metode penelitian lain misalnya dengan menggunakan penelitian kualitatif deskriptif dan atau juga bisa menggabungkan dengan variabel lain untuk mencari hubungan dan besarnya pengaruh yang ditimbulkan.

\section{SIMPULAN DAN IMPLIKASI}

Berdasarkan hasil penelitian diperoleh bahwa pengurus organisasi Mapala yang memiliki kategori perilaku lingkungan yang tinggi sebanyak 41 orang (53.2\%) dan yang rendah adalah 36 orang (46.8\%). Implikasi praktis dari penelitian ini adalah bagi UKM Mapala untuk dapat lebih meningkatkan kontribusi baik secara tenaga maupun finansial dalam upayanya mendukung kelestarian alam dan lingkungan. UKM Mapala harus memiliki inisiatif sendiri dalam upayanya menjaga kelestarian alam dan lingkungan melalui program-program kerjanya. Dalam hal ini diharapkan akan memberikan dampak positif untuk keberlangsungan kelestarian alam dan lingkungan. Sehingga bisa menjadi sebuah momentum untuk memberikan contoh kepada masyarakat umum untuk turut serta dan berkontribusi dalam melestarikan alam dan lingkungan. 


\section{REFERENSI}

Abrams, J., Kelly, E., Shindler, B., \& Wilton, J. (2005). Value orientation and forest management: The forest health debate. Environmental Management. https://doi.org/10.1007/s00267-0047256-8

Arifina, (2019). “Tanam 1000 Pohon Hingga Pelepasan Satwa Warnai Hari Peduli Sampah”. Radar Malang, 21 Febuary 2019.

Azwar, S. (2013). Sikap Manusia: Teori dan Pengukurannya. Sikap Manusia: Teori dan Pengukurannya. https://doi.org/10.1038/cddis.2011.1

Bamberg, S., \& Möser, G. (2007). Twenty years after Hines, Hungerford, and Tomera: A new meta-analysis of psycho-social determinants of pro-environmental behaviour. Journal of Environmental Psychology. https://doi.org/10.1016/j.jenvp.2006.12.002

Rbertson, J. L., \& Barling, J. (2015). Introduction. In The Psychology of Green Organizations. https://doi.org/10.1093/acprof:oso/9780199997480.003.0001

Brown, G., \& Reed, P. (2000). Validation of a forest values typology for use in national forest planning. Forest Science.

Dewi, N., Rusdarti, \& Sunarto, S. (2017). Pengaruh Lingkungan Keluarga , Teman Sebaya , Pengendalian Diri dan Literasi Keuangan Terhadap Perilaku Konsumtif Mahasiswa. JEE. https://doi.org/ISSN : 2301-7341

Gea, Y. E., Anward, H. H., \& Erlyani, N. (2018). Peranan Atraksi Interpersonal Terhadap Perilaku Pro-Lingkungan. Jurnal Ecopsy. https://doi.org/10.20527/ecopsy.v1i2.492

Frank, D. J., \& Meyer, J. W. (2007). University expansion and the knowledge society. Theory and Society. https://doi.org/10.1007/s11186-007-9035-z

Greaves, M., Zibarras, L. D., \& Stride, C. (2013). Using the theory of planned behavior to explore environmental behavioral intentions in the workplace. Journal of Environmental Psychology. https://doi.org/10.1016/j.jenvp.2013.02.003

Homburg, A., \& Stolberg, A. (2006). Explaining pro-environmental behavior with a cognitive theory of stress. Journal of Environmental Psychology. https://doi.org/10.1016/j.jenvp.2006.03.003

Irfianti, M. D. Khanafiyah, S. \& Astuti, B. (2016). Perkembangan Karakter Peduli Lingkungan Melalui Model Experiential Learning. Unnes Physics Education Journal 5(3): $72-79$

Iskadar, Z. (2012). Psikologi Lingkungan Teori dan Konsep. Bandung: Refika Aditama.

Jambeck, J. R. (2015). Plastic waste inputs from land to ocean. Science. https://doi.org/10.1017/CBO9781107415386.010

Kaiser, F. G., Oerke, B., \& Bogner, F. X. (2007). Behavior-based environmental attitude: Development of an instrument for adolescents. Journal of Environmental Psychology. https://doi.org/10.1016/j.jenvp.2007.06.004

Keraf, A. Sonny. (2010). Etika Lingkungan Hidup. Jakarta: Penerbit Buku Kompas.

Kollmuss, A., \& Agyeman, J. (2002). Environmental Education Research. Environmental Education Research. https://doi.org/10.1080/1350462022014540

Lozano, R. (2006). Incorporation and institutionalization of SD into universities: breaking through barriers to change. Journal of Cleaner Production. https://doi.org/10.1016/j.jclepro.2005.12.010

Nordlund, A. M., \& Garvill, J. (2002). Value structures behind proenvironmental behavior. Environment and Behavior. https://doi.org/10.1177/001391602237244

Putra, T. P., Adyatma, S., \& Normelani, E. (2016). Analisis Perilaku Masyarakat Bantaran Sugnai Martapura dalam Aktivitas Membuang Sampah Rumah Tangga di Kelurahan Basirih Kecamatan Banjarmasin Barat. Jurnal Pendidikan Geografi

Robertson, J. L., \& Barling, J. (2015). Introduction. In The Psychology of Green Organizations. https://doi.org/10.1093/acprof:oso/9780199997480.003.0001 
Robertson, J. L., \& Barling, J. (2013). Greening organizations through leaders' influence on employees' pro-environmental behaviors. Journal of Organizational Behavior. https://doi.org/10.1002/job.1820

Saputra, H., Febriana, S. K. T., \& Akbar, S. N. (2018). Pengaruh Peran Kepemimpinan terhadap Perilaku Pro-Lingkungan pada anggota organisasi Mahasiswa Pecinta Alam (MAPALA) Piranha. Jurnal Ecopsy. https://doi.org/10.20527/ecopsy.v3i3.2667

Suryana, Sugiyono, Sekaran, U., Lee, S., Stearns, T., \& Geoffrey, G. M. (2013). Metode Penelitian Kuantitatif, Kualitatif, dan R\&D. International Journal of Management.

Suryanto, (2018). "Susur sungai brantas, gubernur Khofifah Berantas Sampah Pokok".

Radar Surabaya, 12 Februari 2019.

Valentin, J., \& Gamez, L. (2010). Environmental psychology: New developments. Vasa.

Andrews, D. (2003). System Analysis \& Design Methods. Data Processing. https://doi.org/10.1016/0011-684x(86)90236-4

Yusrianti, Y. (2015). Studi Literatur tentang Pencemaran Udara Akibat Aktivitas Kendaraan Bermotor di Jalan Kota Surabaya. Al-Ard: Jurnal Teknik Lingkungan. https://doi.org/10.29080/alard.v1i1.29

Zsóka, Á., Szerényi, Z. M., Széchy, A., \& Kocsis, T. (2013). Greening due to environmental education? Environmental knowledge, attitudes, consumer behavior and everyday proenvironmental activities of Hungarian high school and university students. In Journal of Cleaner Production. https://doi.org/10.1016/j.jclepro.2012.11.030 